\title{
Redemocratização e hegemonia: educação política e movimentos populares nos anos 1978-1989
}

Doutorando em Educação pela Universidade Federal Fluminense

\section{Resumo}

Desde os anos 1960, muitos educadores populares atuaram no Brasil com “objetivos políticos", buscando construir uma hegemonia popular alcançada "antes de conquistar o poder governamental". Pretende-se pesquisar a contribuição dessa síntese fecunda entre educação e política nos movimentos populares para o declínio do regime autoritário e para o fortalecimento de um projeto popular de democracia, que disputou a hegemonia política nos anos 1978-1989, bem como analisar os desdobramentos, limites e possibilidades atuais desse projeto, através da consulta a documentos e fontes bibliográficas, além de entrevistas.

Palavras-chave: Educação Política; Movimentos Populares; Hegemonia.

\begin{abstract}
Since the 1960s, many popular educators worked in Brazil with "political objectives", seeking to build a popular hegemony achieved "before winning governmental power". The aim is to investigate the contribution of this fruitful synthesis between education and politics in the popular movements for the decline of the authoritarian regime and the strengthening of a popular democracy, which ran for political hegemony in the years 1978-1989, and analyze the developments, limits and present possibilities of this project, through documents, bibliographic sources and interviews.
\end{abstract}

Keywords: Political Education; Popular Movements; Hegemony. 


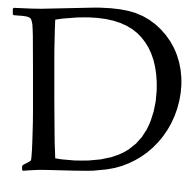

esde os anos 1960, uma vertente da educação popular atuou no Brasil com "objetivos políticos", buscando possibilitar as condições para a construção de uma hegemonia popular alcançada "antes de conquistar o poder governamental", envolvendo inúmeros educadores populares que ajudaram a construir "experiências político-pedagógicas populares" a partir de uma reciprocidade fecunda e singular entre educação e política (SEMERARO, 2004, p.57-58).

A educação popular foi se tornando cada vez mais um "ato político", cujo horizonte era buscar uma "ação educativa criticizadora" (FREIRE, 1989, p.88). O objetivo geral da pesquisa é investigar, no contexto da redemocratização brasileira, mais especificamente entre os anos 1978-1989, a migração de forças políticas que atuavam em oposição à ditadura para o novo ambiente de uma sociedade civil em expansão. Pretendemos pesquisar a contribuição da educação política nos movimentos populares para o declínio do regime autoritário e para o fortalecimento desse projeto político que tencionava "expandir para toda a sociedade a democracia popular" (SEMERARO, 2007, p.100-101), numa expressão da vontade "das classes subalternas que querem educar a si mesmas na arte de governo" (GRAMSCI, 2004, v.1, p.388). Para isso, era necessário mais que contraporse ao Estado autoritário, "era preciso conquistar espaços na complexa rede da sociedade civil e organizar-se como sociedade política" (SEMERARO, 2009, p.109).

Acreditamos que é nesse contexto que se aprofunda e se fortalece o projeto democrático-popular, para inseri-lo de forma intensa na disputa pela hegemonia durante os anos 1980. A redemocratização brasileira acabou sendo uma "transição altamente negociada" (MENDONÇA e FONTES, 2004, p.87). O fim da ditadura não representou o início de um regime verdadeiramente democrático, ou parafraseando Gramsci, o "velho" está custando a morrer, enquanto o "novo" ainda não consegue nascer (GRAMSCI, 2002, v.3, p.184). Não por acaso, no final dos anos 1970 e nos 1980, as idéias de Gramsci começam a circular com bastante vigor nos movimentos populares (SEMERARO, 2009, p.110). Tomando a educação 
política como fio condutor, é possível definir o florescimento de um grande ciclo de mobilização popular, do qual organizações como o Partido dos Trabalhadores (PT), fundado em 1980; a Central Única dos Trabalhadores (CUT), em 1983; e o Movimento dos trabalhadores rurais Sem-Terra (MST), que se institucionalizou em 1984. Como essas experiências de educação política se interligam ao fenômeno histórico de mobilização popular que corresponde aos anos 1978-1989, amalgamando uma série de grupos, associações, sindicatos e movimentos em torno da proposta de uma democracia popular? O que foi feito então desse projeto de sociedade, cuja pedra-de-toque era a educação política?

\section{Referências bibliográficas}

FREIRE, P. Educação como prática da liberdade. 19ª ed. Rio de Janeiro: Paz e Terra, 1989.

GRAMSCI, A. Cadernos do cárcere, v.1. $3^{\mathrm{a} e d}$. Rio de Janeiro: Civilização Brasileira, 2004.

GRAMSCI, A. Cadernos do cárcere, v.3. 2ed. Rio de Janeiro: Civilização Brasileira, 2002.

MENDONÇA, S.; FONTES, V. História do Brasil recente: 1964-1992. 4ªed. São Paulo: Ática, 2004.

SEMERARO, G. Libertação e hegemonia. São Paulo: Idéias e Letras, 2009.

SEMERARO, G. Da libertação à hegemonia: Freire e Gramsci no processo de democratização do Brasil. Revista de Sociologia e Politica, Curitiba, PR, no 29, p. 95-104, 2007.

SEMERARO, G. O educador político e o político educador. In SEMERARO, G. (org.). Filosofia e política na formação do educador. São Paulo: Idéias e Letras, 2004. 